Journal of Animal and Veterinary Advances 9 (16): 2207-2213, 2010

ISSN: $1680-5593$

(C) Medwell Journals, 2010

\title{
Serum Electrolytes of Wild and Captive Bluefin Tuna (Thunnus thynnus L.) in Turkish Seas
}

\author{
${ }^{1}$ Fatih Percin, ${ }^{2}$ Sibel Konyalioglu, ${ }^{1}$ Kursat Firat and ${ }^{1}$ Sahin Saka \\ ${ }^{1}$ Department of Aquaculture, Faculty of Fisheries, \\ Ege University, 35100, Bornova, Izmir, Turkey \\ ${ }^{2}$ Department of Biochemistry, Faculty of Pharmacy, \\ Ege University, 35100, Bornova, Izmir, Turkey
}

\begin{abstract}
The aim of the study was to investigate serum electrolytes-sodium $(\mathrm{Na})$, potassium $(\mathrm{K})$, chloride $(\mathrm{Cl})$, Calcium (Ca), Magnesium (Mg) and phosphorus (P) in wild and captive Bluefin Tuna (BFT) in the Eastern Mediterranean. For this purpose, 127 individual samples consisting of 62 wild and 65 farmed samples were chosen. The wild fish was obtained from Antalya Bay and the captives were taken from a tuna farm in Ildir Bay (Izmir) during the spring. The mean serum electrolyte levels of wilds were found to be as follows: $209.84 \mathrm{mmol} \mathrm{L}^{-1}, 9.84 \mathrm{mEqL}^{-1}, 183.47 \mathrm{mmol} \mathrm{L}^{-1}, 7.49 \mathrm{mEq} \mathrm{L}^{-1}, 7.83 \mathrm{mg} 100 \mathrm{~mL}^{-1}, 5.03 \mathrm{mg} 100 \mathrm{~mL}^{-1}$. Analogous data for the captive fish were detected as follows: $205.85 \mathrm{mmol} \mathrm{L}^{-1}, 6.46 \mathrm{mEq} \mathrm{L}^{-1}, 180.45 \mathrm{mmol} \mathrm{L}^{-1}, 7.19 \mathrm{mEqL}^{-1}$,

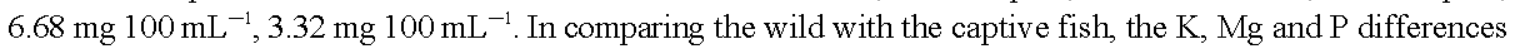
were significant, except for $\mathrm{Na}, \mathrm{Ca}$ and $\mathrm{CL}(\mathrm{p}<0.05)$. On the other hand in terms of gender, the mean serum electrolyte levels of 30 wild and 30 captive individual female BFT were determined, respectively to be as follows: $\mathrm{Na}, 205.58,201.47 \mathrm{mmolL}^{-1} ; \mathrm{K}, 8.73,6.38 \mathrm{mEqL}^{-1}$; $\mathrm{CL}, 186.25,182.63 \mathrm{mmol} \mathrm{L}^{-1}$; $\mathrm{Ca}, 7.19,6.71 \mathrm{mEqL}^{-1}$; Mg, 5.92 ,

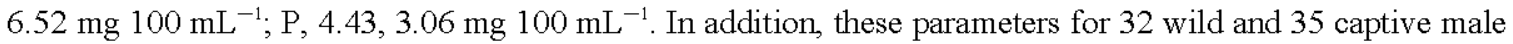
specimens were detected, respectively to be as follows: Na, $214.09,210.23 \mathrm{mmolL}^{-1}, \mathrm{~K}, 10.95,6.54 \mathrm{mEqL}^{-1}$; CL, $180.68,178.27 \mathrm{mmol} \mathrm{L}^{-1}$; $\mathrm{Ca}, 7.78,7.67 \mathrm{mEq} \mathrm{L}{ }^{-1} ; \mathrm{Mg}, 8.47,6.83 \mathrm{mg} 100 \mathrm{~mL}^{-1} ; \mathrm{P}, 5.62,3.58 \mathrm{mg} 100 \mathrm{~mL}^{-1}$. According to gender, the differences in $\mathrm{K}, \mathrm{Mg}$ and $\mathrm{P}$ in wild vs. captive female and wild vs. captive male samples were significant $(\mathrm{p}<0.05)$. However, the $\mathrm{Na}, \mathrm{Cl}$ and $\mathrm{Ca}$ differences were not significant between wild and captive female and male specimens ( $>0.05$ ).
\end{abstract}

Key words: Bluefin tuna, Thunnus thynnus, serum electrolytes, sodium, potassium, chloride, calcium, magnesium, phosphorus

\section{INTRODUCTION}

Tunas comprise seven species of migratory endothermic fish and one of them, the genus Thunnus thynnus is of great commercial value. Since the mid 1990s, the Bluefin Tuna (BFT) trade in Mediterranean coastal waters has developed substantially in order to achieve, a greater fat percentage in the muscle which is considerably desired in the sushi and sashimi markets in Japan and a better price through not flooding the market in the brief fishing period (June-July) (Ottolenghi, 2008; Percin and Akyol, 2010a).

Generally, BFT are captured from the wild and are transferred to floating cages. For 6-10 months, the fish are fed with fresh or frozen food which consists predominantly of sardines, mackerel, pilchard and mollusc. At the end of this period, the BFT are harvested quickly, chilled and exported to Japan. Thus several factors such as food quality, stocking density, quantity, physical and chemical variables, contaminants and harvesting techniques might affect the welfare and flesh quality of fish. Especially during the farming process, the $\mathrm{O}_{2}$ consumption of BFT is increased because they are highly active and fast growing increasing their weight by $25-35 \%$. Hence, the impact of panicking and stress in cages leads to increased mortality rates on farms over those in the wild by at least 10 or $15 \%$. In other words, cage confining stress might lead to suppressing the immune system, giving rise to metabolic and nonmetabolic diseases and mortality e.g., cardiovascular diseases, renal impairments and liver diseases (Leatherland and Woo, 1998; Brill and Bushnell, 2001; Aguado-Gimenez and Garcia-Garcia, 2005; EFSA, 2009; Percin and Akyol, 2010b).

Corresponding Author: Fatih Percin, Department of Aquaculture, Faculty of Fisheries, Ege University, 35100, Bornova, Izmir, Turkey 
Although BFT is an important aquaculture fish species, few diagnostic tools are available to assess the health of individual fish. Clinical chemistry analyses are not used extensively in fish medicine due to the lack of reference intervals. However, they do provide valuable information as the animals do not have to be scarified to obtain tissues for analyses (Stoskopf, 1993). Health evaluation in warm-blooded vertebrates has been facilitated through the development of an extensive database of normal blood chemistry values as well as by an increased understanding of the causes for departures from the norm. Normal ranges for several blood chemistry variables have been established for some mainly cultured, fish species (e.g., carp, salmon, trout, tilapia) but these are rare as yet for bluefin tuna (Hrubec and Smith, 2000; Harikrishnan et al., 2003; Thomas et al., 2003; Clarke et al., 2007).

The blood electrolytes which are sodium $(\mathrm{Na})$, potassium $(\mathrm{K})$, Chloride $(\mathrm{Cl})$, Calcium (Ca), Magnesium (Mg) and Phosphorus (P) are commonly used to determine the physiological characteristics, toxicity and health status of fish. Monovalent ions namely, sodium $\left(\mathrm{Na}^{+}\right)$, potassium $\left(\mathrm{K}^{+}\right)$and Chloride $\left(\mathrm{Cl}^{-}\right)$play an important role in osmoregulation and homeostasis. In vertebrates, the $\mathrm{Na}$ concentration in the extracellular fluid surpasses that in the cytosol whereas $\mathrm{K}$ is higher in the intracellular fluid compared to the plasma. In fish, $\mathrm{Na}$ enters the gill cells from the blood, co-transported with $\mathrm{K}$ and $\mathrm{Cl}$ and driven by an electrochemical gradient favourable to $\mathrm{Na} . \mathrm{Cl}$ exits the apical portion of the cell through a channel that is very similar to the defective structure that produces cystic fibrosis in animals. $\mathrm{Na}$ is transported back across the basolateral membrane into the blood by $\mathrm{Na} / \mathrm{K}$ activated ATPase. Furthermore, the $\mathrm{Na} / \mathrm{K}$ ratio is vital for the ion permeability barriers in the cell membrane. CL is connected to an imbalance of acid-base regulation (Evans, 1993).

One of the divalent ions, calcium $\left(\mathrm{Ca}^{++}\right)$, serves a number of functions in fish. It combines with phosphorus (P) for the deposition of bone. It is possible that bone serves as a reservoir of calcium for plasma and tissues. Additionally, $\mathrm{Ca}$ appears to be important in the reproduction and mitochondrial functions. It is generally recognized that $\mathrm{Ca}$ has an important role in osmoregulation (Wurst and Stickney, 1989). Another divalent ion, magnesium $(\mathrm{Mg}++)$, serves as a cofactor of phosphohydrolases and phosphotransferases. Phosphorus plays important roles in growth and bone mineralization and also in lipid and carbohydrate metabolism. In addition to being a component of bone, $\mathrm{Mg}$ occurs in many metalloenzymes and during $\mathrm{Mg}$ deficiency many metabolic functions are affected e.g., liver cirrhosis and renal calcinosis. Thus, the levels of serum electrolytes offer important knowledge concerning the health status of diseases of and impact of stress on fish (Wurst and Stickney, 1989; Evans, 1993).

Consequently in the present study, the values of $\mathrm{Na}$, $\mathrm{K}, \mathrm{Cl}, \mathrm{Ca}, \mathrm{Mg}$ and $\mathrm{P}$ which are considered as important indicators of the health and physiological conditions of BFT have been investigated in wild and captive and female and male specimens.

\section{MATERIALS AND METHODS}

Sampling and experimental design: Wild BFT were obtained by purse seine from the Levantine Sea in the Bay of Antalya. Captive BFT were taken from the cages of a processing plant in Ildir Bay, Cesme-Izmir. The shape of the cages was conical with a diameter of $50 \mathrm{~m}$ on the surface and $30 \mathrm{~m}$ on the bottom and a depth of $30 \mathrm{~m}$ (Percin and Konyalioglu, 2008). Stock densities were supposed to be $4-6 \mathrm{kgm}^{3} /$ cages but mainly reach to $8 \mathrm{kgm}^{3}$ with 2000-4000 fish/cage. The fattening period in the cages was approximately 7-8 months. Fish were fed ad libitum at approximately $8-10 \%$ of their average overall body weight.

Generally, feedings occurred twice per day with fresh or defrosted food fish such as herring (Clupea harrengus), sardines (Sardina pilchardus, Sardinella aurita), mackerel (Scomber scombrus) and squid (Sephia officinalis). Most of the diet consists of sardines (30-50\%) and herring (30-40\%), supplemented with lesser amounts of mackerel (20-25\%) and squid (10-15\%). The mean daily feeding rate was almost $17-18 \%$ and the food conversion ratio was about 15:1-18:1. Both wild and captive specimens were sampled from winter through spring. The physical parameters of working areas were measured for such elements as dissolved oxygen, temperature and salinity by Oxyguard Handy Gamma (Oxyguard Int. A/S, Denmark). Turbidity and $\mathrm{pH}$ values were determined using a Secchi disk and a digital $\mathrm{pH}$ meter (Hanna Inst., Woonsocket, RI, USA).

The fork length, total weight and gender of the BFT were determined. Wild specimens were captured by purse seine and they were placed on the deck for 5-10 min. Later, the BFT were bled and the blood samples were taken using a vacutainer. After that the fish were gutted. The divers restrained the captive fish by using a net in the cages. Then the fish were caught and prepared for the aforementioned analysis for an additional 5-10 min; no anaesthetics or sedatives were used. 
Blood collection: Blood samples were taken from the pectoral vein with a sterile vacutainer. Then they were transferred to sterile tubes and clotted for a few minutes (approximately $3-5 \mathrm{~min}$ ) before the centrifugation. Later, all blood samples were centrifuged at $3000 \mathrm{~g}(5000 \mathrm{rpm})$ for 5-7 min. Serum samples were transferred to other sterile tubes and all of them were placed in $\mathrm{CO}_{2}$ ice and stored at $-70^{\circ} \mathrm{C}$ until the analyses started.

Analyses methods: Before analyses, the frozen serum samples were left at room temperature to thaw, then inverted several times to mix. The samples for each individual (specimens) were analyzed together in one batch to avoid run to run variability for the following analyses: sodium $(\mathrm{Na})$, potassium $(\mathrm{K})$, Chloride $(\mathrm{Cl})$, Calcium (Ca), Magnesium (Mg) and Phosphorus (P). Ca, $\mathrm{Mg}$ and $\mathrm{P}$ analyses were performed using a Synchron LX 20 blood chemistry analyzer (Beckmann Coulter, High Wycombe, UK) with Beckmann Coulter reagents. Na, K and $\mathrm{Cl}$ analyses were measured with an Ion-Selective Electrodes method(ISE) using a Beckmann Synchron EL-ISE Electrolyte System which consisted of a Universal Diluent Electrolyte System and Universal Reference reagents by Beckmann Coulter (High Wycombe, UK).

Statistical analysis: The measurements of serum samples were carried out in triplicate and all detected data were subjected to statistical analysis. Range values were given. Correction matrices were produced in order to examine the inter-relationships between the investigated serum electrolytes of the samples. The mean and Standard Error (SE) values were determined and compared using the student's t-test. The mean differences of the serum electrolytes were shown for the wild and captive and for the female and male BFT and one-way Analysis Of Variance (ANOVA) was performed on the available data. Differences were considered significant at $\mathrm{p}<0.05$.

\section{RESULTS AND DISCUSSION}

Water-quality parameters: Both working areas of Ildir Bay and Antalya Bay were measured for winter and early summer temperatures, dissolved oxygen, salinity, $\mathrm{pH}$ and turbidity levels. About 10 samplings were carried out in each area for each season. The range values of temperature, dissolved oxygen and salinity around the farming areas of Ildir Bay were determined as follows, respectively: $16-19^{\circ} \mathrm{C}, 8.05-8.20 \% \mathrm{mg} \mathrm{L}^{-1}$ and $36.8-37.3 \%$. The same parameters around the Antalya Bay were found to be as follows, respectively: $19-22^{\circ} \mathrm{C}, 7.10-7.20 \% \mathrm{mg} \mathrm{L}^{-1}$, $37.9-38.3 \%$. The range values of $\mathrm{pH}$ were measured at between 8.0 and 8.2 in Ildir Bay and 7.8 and 8.0 in Antalya
Bay. The turbidity levels in both sampling areas were between 14 and 16 and 26 and $28 \mathrm{~m}$, respectively. According to the results, the dissolved oxygen and $\mathrm{pH}$ values were higher at Ildir Bay than at Antalya Bay while the salinity and temperature were lower. Hence, the water quality results were within the acceptable limits for aquacultured areas such as farms for bluefin tuna and other types of fish in Ildir Bay, Turkey and these areas did not contain any pollutants.

Physical properties of fish: The fork length and weight of 62 wild and 65 fattened BFT were determined to be as follows: $156.3 \pm 2.1 \mathrm{~cm}$ and $55.3 \pm 1.9 \mathrm{~kg}$ and $159.1 \pm 2.6 \mathrm{~cm}$ and $58.7 \pm 2.2 \mathrm{~kg}$, respectively. Among the wild BFT, 30 of the samples were female $(159.4 \pm 2.4 \mathrm{~cm} ; 57.7 \pm 2.3 \mathrm{~kg})$ and 32 of the samples were male $(153.2 \pm 1.6 \mathrm{~cm} ; 52.9 \pm 1.3 \mathrm{~kg})$. Among the fattened BFT, 30 of the samples were female $(160.2 \pm 2.5 \mathrm{~cm} ; 59.9 \pm 2.4 \mathrm{~kg})$ and 35 of the samples were male $(158.0 \pm 2.2 \mathrm{~cm} ; 57.5 \pm 2.1 \mathrm{~kg})$. The wild and farmed BFT were found to have nearly identical fork lengths and weights. The fish were specifically harvested in order to obtain specimens within a particular age class because serum electrolyte levels might change with size and age. Attempts were made to decrease the possibility of age related differences in these measured parameters by choosing samples of similar fork lengths and weights. Hence in the study, the BFT were approximately 6-7 years old (Cort, 1991; Percin and Akyol, 2009; Santamaria et al., 2009; Percin and Akyol, 2010a).

Serum electrolyte levels: All finding values are detailed in the following tables: The serum electrolyte results for the wild and captive fish are shown in Table 1; the serum electrolyte results for the wild and captive female and male BFT are shown in Table 2 and 3 and finally, the significance of differences between the female and male BFT is shown in Table 4.

According to Table 1, all serum electrolyte levels were higher in wild BFT and $\mathrm{K}, \mathrm{Mg}$ and $\mathrm{P}$ levels were significant for captive $\mathrm{BFT}$ with the exception of $\mathrm{Na}, \mathrm{Cl}$ and $\mathrm{Ca}(\mathrm{p}<0.05)$. Thus, $\mathrm{K}, \mathrm{Mg}$ and $\mathrm{P}$ values are related mainly to the cell metabolism and the metalloenzymes of bone, renal impairment or growth hormone deficiency (Stoskopf, 1993; Leatherland and Woo, 1998).

In addition, according to the tables that detail female wild and captive BFT (Table 2 and 4), serum electrolyte levels for wild females were higher. The differences for $\mathrm{K}$, $\mathrm{Mg}$ and $\mathrm{P}$ between wild and captive female specimens were significant with the exception of $\mathrm{Na}, \mathrm{Cl}$ and $\mathrm{Ca}$ $(\mathrm{p}<0.05$ ). Similarly, among male shown in Table 3 and 4, all of the measured parameters were higher in wild males but 
Table 1: Serum electrolyte levels of wild and fattened bluefin tuna

\begin{tabular}{lrrrr}
\hline Parameters & \multicolumn{1}{c}{ Wild (n:62) } & \multicolumn{1}{c}{ Range } & Captive (n:65) & \multicolumn{1}{c}{ Range } \\
\hline $\mathrm{Na} \mathrm{mmol} \mathrm{L}$ & $209.84 \pm 10.82$ & $194.65-218.22$ & $205.85 \pm 9.79$ (NS) & $189.33-217.30$ \\
$\mathrm{~K} \mathrm{mEq} \mathrm{L}^{-1}$ & $9.84 \pm 2.160$ & $5.92-14.300$ & $6.46 \pm 1.76^{*}$ & $5.16-8.2900$ \\
$\mathrm{Cl} \mathrm{mmol} \mathrm{L}^{-1}$ & $183.47 \pm 7.950$ & $173.51-190.72$ & $180.45 \pm 7.67$ (NS) & $166.83-191.57$ \\
$\mathrm{Ca} \mathrm{mEq} \mathrm{L}^{-1}$ & $7.49 \pm 1.540$ & $5.71-9.2400$ & $7.19 \pm 1.75$ (NS) & $5.47-9.0300$ \\
$\mathrm{Mg} \mathrm{mg} \mathrm{100} \mathrm{mL}^{-1}$ & $7.83 \pm 2.870$ & $2.48-11.390$ & $6.68 \pm 1.79^{*}$ & $5.03-8.3200$ \\
P mg 100 mL & $5.03 \pm 1.010$ & $1.93-9.5700$ & $3.32 \pm 0.90^{*}$ & $1.57-6.6900$ \\
\hline
\end{tabular}

${ }^{*} \mathrm{p}<0.05 ;$ NS: Not Significant; $n$ : number of samples

Table 2: Serum electrolyte levels of wild and captive female bluefin tuna

\begin{tabular}{|c|c|c|c|c|}
\hline Parameters & Wild (n:30) & Range & Captive (n:30) & Range \\
\hline $\mathrm{Na} \mathrm{mmol} \mathrm{L}^{-1}$ & $205.58 \pm 9.92$ & $194.65-213.47$ & $201.47 \pm 9.51$ & $189.33-210.76$ \\
\hline $\mathrm{K} \mathrm{mEq} \mathrm{L}^{-1}$ & $8.73 \pm 1.93$ & $5.92-11.270$ & $6.38 \pm 1.54$ & $5.16-8.2900$ \\
\hline $\mathrm{Cl} \mathrm{mmol} \mathrm{L}-1$ & $186.25 \pm 7.76$ & $178.46-190.72$ & $182.63 \pm 7.41$ & $170.19-188.75$ \\
\hline $\mathrm{Ca} \mathrm{mEq} \mathrm{L}^{-1}$ & $7.19 \pm 1.62$ & $5.71-9.2400$ & $6.71 \pm 1.62$ & $5.47-8.6300$ \\
\hline $\mathrm{Mg} \mathrm{mg} 100 \mathrm{~mL}^{-1}$ & $5.92 \pm 1.56$ & $2.86-7.3300$ & $6.52 \pm 1.13$ & $5.18-6.7900$ \\
\hline P mg $100 \mathrm{~mL}^{-1}$ & $4.43 \pm 0.96$ & $1.93-9.5700$ & $3.06 \pm 0.75$ & $2.78-6.6900$ \\
\hline
\end{tabular}

${ }^{*} \mathrm{p}<0.05$; NS: Not Significant; $n$ : number of samples

Table 3: Serum electrolyte levels of wild and captive male bluefin tuna

\begin{tabular}{|c|c|c|c|c|}
\hline Parameters & Wild (n:32) & Range & Captive (n:35) & Range \\
\hline $\mathrm{Na} \mathrm{mmol} \mathrm{L}^{-1}$ & $214.09 \pm 10.53$ & $207.61-218.22$ & $210.23 \pm 10.08$ & $204.98-217.30$ \\
\hline $\mathrm{K} \mathrm{mEq} \mathrm{L}^{-1}$ & $10.95 \pm 2.040$ & $6.48-14.300$ & $6.54 \pm 1.420$ & $5.50-7.4100$ \\
\hline $\mathrm{Cl} \mathrm{mmol} \mathrm{L}-1$ & $180.68 \pm 7.030$ & $173.51-189.60$ & $178.27 \pm 6.940$ & $166.83-191.57$ \\
\hline $\mathrm{Ca} \mathrm{mEq} \mathrm{L} \mathrm{L}^{-1}$ & $7.78 \pm 1.350$ & $6.68-8.5300$ & $7.67 \pm 1.550$ & $5.68-9.0300$ \\
\hline $\mathrm{Mg} \mathrm{mg} 100 \mathrm{~mL}^{-1}$ & $8.47 \pm 2.680$ & $2.48-11.390$ & $6.83 \pm 1.410$ & $5.03-8.3200$ \\
\hline P mg $100 \mathrm{~mL}^{-1}$ & $5.62 \pm 0.950$ & $2.31-7.8200$ & $3.58 \pm 0.860$ & $1.57-4.6500$ \\
\hline
\end{tabular}

${ }^{*} \mathrm{p}<0.05$; NS: Not Significant; $\mathrm{n}$ : number of samples

Table 4: Table of significance in kidney tissue differences between female and male wild/captive BFT

\begin{tabular}{lcccc}
\hline Elements & $\mathrm{W}_{\text {Female }}-\mathrm{W}_{\text {Male }}$ & $\mathrm{W}_{\text {female }}-\mathrm{C}_{\text {Female }}$ & $\mathrm{C}_{\text {female }}-\mathrm{C}_{\text {Male }}$ & $\mathrm{C}_{\text {male }}-\mathrm{W}_{\text {Male }}$ \\
$\mathrm{Na}$ & $\mathrm{NS}$ & $\mathrm{NS}$ & $\mathrm{NS}$ & $\mathrm{NS}$ \\
$\mathrm{K}$ & $*$ & $*$ & $\mathrm{NS}$ & $*$ \\
$\mathrm{Cl}$ & $\mathrm{NS}$ & $\mathrm{NS}$ & $\mathrm{NS}$ & $\mathrm{NS}$ \\
$\mathrm{Ca}$ & $\mathrm{NS}$ & $\mathrm{NS}$ & $*$ & $\mathrm{NS}$ \\
$\mathrm{Mg}$ & $*$ & $*$ & $\mathrm{NS}$ & $*$ \\
$\mathrm{P}$ & $*$ & $*$ & $*$ & $*$ \\
$*$ *Significant differences $(\mathrm{p}<0.05)$ & $\mathrm{W}_{\text {Female }}:$ Wild Female, $\mathrm{W}_{\text {Male }}:$ Wild Male, \\
$\mathrm{C}_{\text {Female }}:$ Captive Female, & $\mathrm{C}_{\text {Male }}:$ Captive Male
\end{tabular}

only the differences for $\mathrm{K}, \mathrm{Mg}$ and $\mathrm{P}$ were statistically significant $(\mathrm{p}<0.05)$. These parameters as mentioned before, show that female and male captive BFT are under pressure in cage conditions. Such conditions can result in long-term chronic stress factors so that the fish are easily susceptible to renal tubular disease, cardiac and hepatic failure and bone diseases (Stoskopf, 1993; Reddy and Leatherland, 1998; Pottinger, 2001).

On the other hand, according to the tables for female/male wild and captive BFT (Table 2-4), the $\mathrm{Na}, \mathrm{K}$, $\mathrm{Ca}, \mathrm{Mg}$ and $\mathrm{P}$ values were lower in the wild female BFT but the $\mathrm{Cl}$ level was higher. The differences for $\mathrm{K}, \mathrm{Mg}$ and $\mathrm{P}$ were significant for both wild females and males $(\mathrm{p}<0.05)$. In addition, when captive female and male BFT were compared, all measured parameters were found to be lower in female individuals except the $\mathrm{Cl}$ level and the differences in $\mathrm{Ca}$ and $\mathrm{P}$ levels were significant $(\mathrm{p}<0.05)$. These parameters might indicate that female BFT in both the wild and captive areas are more sensitive and weaker than the males. Long term chronic stress might affect female BFT more thus these fish could be easily susceptible to malignant cell disease, chronic heart failure, renal and liver disease and endocrinal and reproductive disease (e.g., thyroid diseases) (Reddy and Leatherland, 1998; Pottinger, 2001; Schaefer, 2001 ).

Comparison with previous research: Haematological and biochemical values are important for diagnosis of clinical signs showing how diseases progress over time. Also, the use of haematological parameters as indicators of the sublethal effects of stress can provide information on the physiological responses fish make to changing external environmental conditions (Casillas and Smith, 1977; EFSA, 2009). The long-term chronic stress responses resulting from the physiological effects of various factors such as farming conditions can be measured by the assessment of a range of haematological parameters (Kjartansson et al., 1988; Stoskopf, 1993; EFSA, 2009).

Blood electrolyte research has been focussed mainly on physiology (osmoregulation), biochemistry (acid-base regulation), metabolic diseases (renal and hepatic disease) and toxicity in cultured fishes e.g., tilapia, carp, salmon, trout (Casillas and Smith, 1977; Hrubec et al., 2000; Harikrishnan et al., 2003; Silkin and Silkina, 2005; Petri et al., 2006). However, there are few studies on serum or plasma biochemistry and the electrolyte levels of tunas especially in cultured BFTs. Although, Hrubec and Smith (2000), Thomas et al. (2003), Clarke et al. (2007) and Percin and Konyalioglu (2008) have studied the blood biochemistry of tunas, there is still a lack of basic data. On 
the other hand, the baseline hematologic parameters are available for albacore and skipjack tuna (Horney, 1993) as well as for yellowfin tuna (Wells et al., 1986). Popovic et al. (2008) determined the plasma electrolytes in 65 individually sea-caged BFT $(245.4 \mathrm{~cm}$ fork length and $275.6 \mathrm{~kg}$ ) in the Adriatic Sea. They found the values to be as follows: $\mathrm{Na}, 245.3 ; \mathrm{K}, 6.6 ; \mathrm{Cl}, 228.9 ; \mathrm{Ca}, 5.3 ; \mathrm{P}, 1.7$ (mmol L ${ }^{-1}$ ). In the study the $\mathrm{Na}$ and $\mathrm{Cl}$ levels were detected as 209.84, 205.85 and 183.47, $180.45\left(\mathrm{mmol} \mathrm{L}^{-1}\right)$ in wild and captive BFT, respectively. The Na values in wild and penned fish were similar to those reported by Popovic et al. (2008) but the CL levels in the findings were lower compared to theirs. Moreover, $\mathrm{K}, \mathrm{Ca}$ and p-values in this research were determined to be $9.84,6.46(\mathrm{mEq}$ $\left.\mathrm{L}^{-1}\right) ; 7.49,7.19\left(\mathrm{mEqL}^{-1}\right)$ and 5.03, $3.32\left(\mathrm{mg} 100 \mathrm{~mL}^{-1}\right)$, respectively. The $\mathrm{K}$ and $\mathrm{Ca}$ levels were parallel with those of Popovic et al. (2008) but the P levels were higher in both wild and captive BFT.

On the other hand in Popovic et al. (2008), all the measuring data were given as $\mathrm{mmol} \mathrm{L}^{-1}$. In the research, $\mathrm{Na}$ and $\mathrm{Cl}$ were measured as $\mathrm{mmol} \mathrm{L}^{-1} ; \mathrm{K}$ and Ca values were detected as $\mathrm{mEq} \mathrm{L} \mathrm{L}^{-1}$ and $\mathrm{Mg}$ and $\mathrm{P}$ levels were found as $\mathrm{mg} 100 \mathrm{~mL}^{-1}$. The differences in measurement units between these two studies could be a factor in the obtaining of different results. Another reason for the differences in the serum electrolytes might be related to sample size. Popovic et al. (2008) researched on big fish which were $245.4 \mathrm{~cm}$ fork length and $275.6 \mathrm{~kg}$. According to some researchers (Cort, 1991; Percin and Akyol, 2009; Santamaria et al., 2009; Percin and Akyol, 2010a) the predictive age range for the sea-cage-reared fish studied by Popovic et al. (2008) was approximately $15+$ years. In the study, the fork length and weight of wild and penned BFT were nearly the same at $156.3 \pm 2.1 \mathrm{~cm}$ and $55.3 \pm 1.9 \mathrm{~kg}$ and $159.1 \pm 2.6 \mathrm{~cm}$ and $58.7 \pm 2.2 \mathrm{~kg}$, respectively. Thus, the predictive age range for the fish was almost 6-7 years. Hence, the different fork length, weight and age scores might have influenced the results of the serum electrolytes levels in the two research studies.

Percin and Konyalioglu (2008) determined and compared of serum biochemistry profiles between wild and captive BFT. They concluded that fattened BFT were more under stress conditions in farmed area depends on wild specimens. Also, Percin and Akyol (2010a) studied on some morhometric relationships in captive BFT. They reported that the body shape of captive BFT changed from fusiform to obese due to farm conditions such as over feeding. It is known that obesity is influenced to cardiovascular system which is harmful to health of heart. Consequently, the results of serum electrolyte levels in the research may be supported and strengthened by the results of Percin and Konyalioglu (2008), Popovic et al. (2008) and Percin and Akyol (2010a).

\section{CONCLUSION}

Since biochemical variables can be used to assess the health status of fish, a biochemical characterization of clinically healthy wild/farmed Bluefin Tuna (BFT) was done to establish the reference indices for this species. In this research, the $\mathrm{Na}, \mathrm{K}, \mathrm{Cl}, \mathrm{Ca}, \mathrm{Mg}$ and $\mathrm{P}$ levels in the serum samples of all BFT were detected to be $207.85 \mathrm{mmol} \mathrm{L}^{-1} ; 8.15 \mathrm{mEq} \mathrm{L}^{-1} ; 181.96 \mathrm{mmol} \mathrm{L}^{-1}$; $7.34 \mathrm{mEq} \mathrm{L}^{-1} ; 7.25 \mathrm{mg} 100 \mathrm{~mL}^{-1} ; 4.18 \mathrm{mg} 100 \mathrm{~mL}^{-1}$, respectively. The data indicate that serum electrolyte levels were higher in wild female/male BFT than in the captive specimens. Also, these parameters in both wild and captive female specimens were lower than those of males. The results demonstrate that captive fish may be under more pressure and hence sensitive. Similarly, female individual BFT were influenced more by the same factors.

The causes of the sensitiveness in captive BFT might be related to changing environmental conditions, physico-chemical interactions, feeding types and food and cage confinement and lack of space in pens. However, the causes of the weakness in female individuals might be influenced by spawning, reproduction, gonad development and farming conditions.

Thus, it is important to document the relationship between lifestyle and stress on wild and fattened fish and also the effect of this relationship on their serum electrolyte levels. Increases or decreases in the serum electrolytes show serious organ failure or damage. In aquacultural treatments, these factors negatively affect the flesh quality, decreasing the price of meat and causing profit losses in farms.

In this study the $\mathrm{Na}, \mathrm{K}, \mathrm{Cl}, \mathrm{Ca}, \mathrm{Mg}$ and p-values in serum samples have been assayed and compared for wild/captive and female/male bluefin tuna (Thunnus thynnus). It is necessary to perform these parameters periodically. The parameters should also be investigated for other bluefin species for purposes of comparison.

\section{ACKNOWLEDGEMENTS}

The researchers wish to thank Hasan Serefoglu, Mustafa Denizer and Asim Kul for their helpful comments and technical assistance in providing blood samples of bluefin tuna and also Dr. Berna Turkekul for reviewing a draft of this manuscript. This research was funded by the Aqua-Dem and Ak-Tuna Fisheries companies. 


\section{REFERENCES}

Aguado-Gimenez, F. and B. Garcia-Garcia, 2005. Growth, food intake and conversion rates in captive Atlantic bluefin tuna (Thunnus thyunnus Linneaus, 1758) under fattening canditions. Aquac. Res., 36: 610-614.

Brill, R.W. and P.G. Bushnell, 2001. The Cardiovascular System of Tunas. In: Tuna: Physiology, Ecology and Evolution, Block, B.A. and E.D. Stevens (Eds.). Academic Press, San Diego, pp: 79-120.

Casillas, E. and L.S. Smith, 1977. Effects of stress on blood coagulation and hematology in rainbow trout (Salmo gairdneri). J. Fish Biol., 10: 481-491.

Clarke, T., R. Seymour and R. Frappell, 2007. Circulatory physiology and haematology of southern bluefin tuna (Thunnus maccoyii). Comperative Biochem. Physiol., 146: 179-179.

Cort, J.L., 1991. Age and growth of bluefin tuna Thunnus thynnus (L.) of the Northeast Atlantic. ICCAT Rep., SCRS/94/66. Madrid, Spain, pp: 86.

EFSA, 2009. Scientific opinion of the panel on animal health and welfare on a request from the European Commission on the species-specific welfare aspects of the main systems of stunning and killing of farmed tuna. EFSA J., 1072: 2-53.

Evans, D.H., 1993. The Physiology of Fishes. 2nd Edn., CRC Press, Boca Raton, pp: 49-73.

Harikrishnan, R., R.M. Nisha and C. Balasundaram, 2003. Hematological and biochemical parameters in common carp, Cyprinus carpio, following herbal treatment for Aeromonas hydrophila infection. Aquaculture, 222: 41-50.

Horney, B., 1993. Clinical Pathology of Cold-Water Marine Fishes. In: Fish Medicine, Stoskopf, M.K. (Ed.). WB Saunders Company, Philadelphia, PA., pp: 685-687.

Hrubec, T.C. and S.A. Smith, 2000. Hematology of Fish. In: Veterinary Hematology, Feldman, B.F., J.G. Zink1 and N.C. Jain (Eds.). Lippincott Williams and Wilkins, Philadelphia, pp: 1120-1125.

Hrubec, T.C., J.L. Cardinale and S.A. Smith, 2000. Hematology and plasma chemistry reference intervals for cultured tilapia (Oreochromis Hybrid). Vet. Clin. Pathol., 29: 7-12.

Kjartansson, H., S. Fivelstad, J.M. Thomassen and M.J. Smith, 1988. Effects of different stocking densities on physiological parameters and growth of adult Atlantic salmon (Salmo salar L.) reared in circular tnaks. Aquaculture, 73: 261-274.
Leatherland, J.F. and P.T.K. Woo, 1998. Fish Diseases and Disorders Vol: 2. Non-infectious Disorders. 2nd Edn., CABI Publishing, Wallingford, London. UK., pp: 395.

Ottolenghi, F., 2008. Capture-based Aquaculture of Bluefin Tuna: Global Overview. In: FAO Fisheries Technical Paper No. 508, Lovatelli, A. and P.F. Holtus (Eds.). FAO of the United Nations, Rome, pp: 298.

Percin, F. and O. Akyol, 2009. Length-weight and length-length relationships of the bluefin tuna, Thunnus thynnus L., in the Turkish part of the eastern Mediterranean Sea. J. Appl. Ichthyol., 25: 782-784.

Percin, F. and O. Akyol, 2010a. A new harvesting techniques for tunas: Lupara. J. Fish. Sci., 4: 190-194.

Percin, F. and O. Akyol, 2010b. Some morphometric relationships in fattened bluefin tuna, Thunnus thynnus L., from the Turkish Aegean Sea. J. Anim. Vet. Adv., 9: 1684-1688.

Percin, F. and S. Konyalioglu, 2008. Serum biochemical profiles of captive and wild northern bluefin tuna (Thunnus thynnus L. 1758), in the Eastern Mediterranean. Aquac. Res., 39: 945-953.

Petri, D., C.N. Glover, S. Ylving, K. Kolas, G. Fremmersvik, R. Waagbo and M.H. Berntssen, 2006. Sensitivity of Atlantic salmon (Salmo salar) to dietary endosulfan as assessed by haematology, blood biochemistry and growth parameters. Aquac. Toxicol., 80: 207-216.

Popovic, N.T., E. Srebocan, R. Coz-Rakovac, M. Hacmanjek, I. Strunjak-Perovic and M. Jadan, 2008. Blood biochemistry of captive Atlantic bluefin tuna Thunnus thynnus farmed in the Adriatic Sea. J. Appl. Ichthyol., 24: 614-616.

Pottinger, T.G., 2001. Effects of Husbandry Stress on Flesh Quality Indicators in Fish. In: Farmed Fish Quality Fishing News Books, Kestin, S. and P.D. Warriss (Eds.). Oxford Press, Oxford, UK., pp: 145-160.

Reddy, P.K. and J.F. Leatherland, 1998. Stress Physiology. In: Fish Diseases and Disorders. Vol. 2: Noninfectious Disorders, Leatherland, J.F. and P.T.K. Woo (Eds.). CABI Publishing, Wallingford, London, UK., pp: 303-335.

Santamaria, N., G. Bello, A. Corriero, M. Deflorio, R. Vassallo-Agius, T. Bok and G. De Metrio, 2009. Age and growth of Atlantic bluefin tuna, Thunnus thynnus (Osteichthyes: Thunnidae), in the Mediterranean Sea. J. Applied Ichthyol., 25: 38-45.

Schaefer, K.M., 2001 . Reproductive Biology of Tunas. In: Tuna: Physiology, Ecology and Evolution, Block, B.A. and E.D. Stevens (Eds.). Academic Press, San Diego, pp: 225-270.

Silkin, Y.A. and E.N. Silkina, 2005. Effect of hypoxia on physiological-biochemical blood parameters in some marine fish. J. Evol. Biochem. Physiol., 41: 527-532. 
Stoskopf, M.K., 1993. Fish Medicine. WB Saunders Company, Philadelphia, PA, pp: 882.

Thomas, P.M., J.F. Carragher, B.D. Glencross and C.G. Carter, 2003. Preliminary information on temporal changes in the blood chemistry of farmed southern bluefin tuna, Thunnus maccoyii (Castelnau), after feeding and repeated sampling disturbance. Aquac. Res., 34: 265-267.
Wells, R.M., R.H. McIntyre, A.K. Morgan and P.S. Davie, 1986. Physiological stress responses in big game fish after capture: observations on plasma chemistry and blood factors. Comp. Biochem. Physiol. A Comp. Physiol., 84: 565-571.

Wurst, W.A. and R.R. Stickney, 1989. Responses of red drum (Sciaenops ocellatus) to calcium and magnesium concentrations in fresh and salt water. Aquaculture, 76: 21-35. 